\title{
Sistem Pemerintahan Daerah Dalam Reformasi Hukum Administrasi Negara
}

Affila, S.H., M. Hum

(Staf Pengajar FH USU)

\begin{abstract}
Abstrak
Hukum administrasi Negara merupakan alat (tool) bagi perwujudan penyelenggaraan Negara, maka reformasi system pemerintahan harus dibarengi Pula dengan reformasi perangkat hukum dalam hal ini hukum administrasi negara.

Kata Kunci : Hukum, Hukum Administrasi Negara.
\end{abstract}




\section{A. Latar Belakang}

Dalam usaha meningkatkan pelayanan publik secara general harus terlebih dahulu dilihat kualitas pelaksanaan sistem pemerintahan. Bagaimana pemerintah menjalankan fungsinya. Kebijaksanaan dalam mengambil keputusan dan kewenangan dalam bertindak merupakan kunci pokok terlaksananya pemerintahan dengan baik. Pendistribusian maupun penyerahan kewenangan kepada pihak yang berkompeten juga menjadi bagian penting, seperti bagaimana pemerintah pusat menyerahkan tugas atau kewenangan yang harus dijalankan pemda merupakan masalah yang urgen saat ini.

Berbeda, dengan sistem otonomi daerah di negara federal, otonomi daerah di Indonesia diletakkan dalam kerangka negara kesatuan (Unitary State). Perbedaan utama sistem federalisme dan unitaristik terletak pada sumber kedaulatan, yaitu dalam sistem federalisme, kedaulatan diperoleh dari unit-unit politik yang terpisahpisah dan kemudian sepakat membentuk sebuah pemerintahan bersama, dalam pemerintahan yang

unitristik kedaulatan ${ }^{1}$ langsung bersumber dari seluruh penduduk dalam negara tersebut.

Menyangkut pemda dari sejak sebelum reformasi sampai Setelah reformasi hingga saat ini telah beberapa peraturan

\footnotetext{
${ }^{1}$ Menurut JJ Rouseuse, John Lock dan Montes quie, kedaulatan negara yang diselenggarakan bersumber dari rakyat.
}

perundangan dikeluarkan untuk menyahuti kebutuhan akan pengaturan tentang pemda. Dari mulai UU No. 1 Tahun 1945, UU No. 5 Tahun 1974, kemudian UU No. 22 Tahun 1999 sampai kepada UU No. 32 Tahun 2004 (UUPD). Dalam peraturan perundangan tentang pemda yang terbaru sebagai pengganti peraturan sebelumnya terlihat sudah lebih memenuhi aspirasi dalam kebutuhan pengaturan tentang pemda.

Secara umum, peraturan ini telah dicantumkan secara tegas dan spesifik tentang hal-hal yang menjadi hak dan kewajiban serta kewenangan dari pemda baik dari tingkat Gubernur, Bupati, Walikota, Camat, maupun Lurah dan atau Desa sampai kepada DPRD propinsi maupun daerah kabupaten kota telah secara tegas dipaparkan.

Namun meskipun sudah diupayakan secara optimal, tetap raja masih dapat dirasakan adanya kekurangan. Dari paparan diatas timbul permasalahan :

1. Bagaimana peran UU dalam pelaksanaan otonomi?

2. Bagaimana peranan reformasi hukum administrasi negara terhadap kebijakan sistem pemda?

\section{B. Peran UU}

Berkaitan dengan pelak-
sanaan otonomi penyelenggaraan pemda yang demokratis dan transparansi serta akuntabel, merupakan isu yang sangat penting dan strategis. Hal tersebut sesungguhnya merupakan konsekuensi logis otonomi daerah yang semestinya memungkinkan: 
1. Semakin dekat pelayanan pemda ke masyarakat;

2. Penyelesaian masalah didaerah menjadi lebih fokus dan mandiri;

3. Partisipasi masyarakat jadi lebih luas dalam pembangunan daerah;

4. Masyarakat melakukan pengawasan intensif terhadap penyelenggaraan pemerintahan daerah.

Keempat faktor tersebut hanya dapat berlangsung dalam pemerintahan yang demokratis dan akuntabel. Otonomi daerah tanpa diimbangi dengan penyelenggaraan pemda yang demokratis, transparan dan akuntabel, pada hakekatnya otonomi daerah tersebut telah

kehilangan jati dirinya dan maknanya $^{2}$.

Hal tersebut tidak lepas dan berkaitan dengan penerapan dan pelaksanaan peraturan perundangundangan yang telah dikeluarkan tentang pemda, telah melahirkan berbagai peraturan, dimulai dari UU No. 22 Tahun 1999, kemudian diubah dan katanya "disempurnakan"3 dengan UUPD.

UU No 2 tahun 1999 dilahirkan sebagai akibat dari kebijakan politik masa itu yang mendengungkan reformasi di setiap kehidupan masyarakat. Termasuk kebijakan public. Secara administrasi negara kebijakan yang dikeluarkan pemerintah dalam bentuk undang-

http://www.rakbuku.com/tsoftcopy/thk.doc

3 sampai saat ini masih banyak permasalahan yang timbul dan belum terselesaikan, seperti sengketa tapal batas wilayah, menjadi kewenangan siapa dalam penyelesaiannya? undang adalah sebagai bagian dari kewenangan yang dimiliki pemerintah untuk menjalankan kekuasaannya ${ }^{4}$.

Saat ini pakar hukum administrasi negara menyebutkan administrasi negara sebagai Sistem Administrasi Negara

Kesatuan Republik Indonesia (SANKRI), yaitu :

Sistem penyelenggaraan kehidupan negara dan bangsa dalam segala aspek nya, dengan

mendayagunakan kemampuan seluruh aparatur negara beserta rakyat dan dunia usaha untuk memanfaatkan segenap sumber daya yang tersedia secara nasional, demi tercapainya tujuan dan terlaksananya tugas negara sebagaimana dimaksud UUD 1945."5

Pemberlakuan UU No. 22 Tahun 1999 memiliki keterkaitan dengan peraturan yang diharapkan menjadi cerminan pendukung kebijakan tersebut, peraturan terkait itu antara lain:

1. UU No. 28 Tahun 1999 Tentang Penyelenggaraan Pemerintahan Yang Bersih dan bebas dari KKN

2. UU No. 25 Tahun 1999 Tentang Perimbangan Keuangan Antara Pemerintah Pusat dan Daerah.

\footnotetext{
4 Miriam Budiarjo, dalam Dasardasar Ilmu Politik Gramedia menyebutkan kekuasaan merupakan kemampuan untuk mempengaruhi seseorang atau kelompok lain, sedemikian rupa sehingga sesuai dengan tujuan dari orang yang memiliki kekuasaan itu. $2005: 10$
} 
3. PP No. 20 Tahun 2001 Tentang Pembinaan dan Pengawasan Penyelenggaraan Pemda

4. Kepmendagri No. 41 Tahun 2001 Tentang Pengawasan Kebijakan Daerah

Dalam perjalanan UU No. 22 Tahun 1999 mulai dirasakan belum memenuhi aspirasi dan kebutuhan perda, hal ini disebabkan karena undang-undang ini lahir di lingkungan transisi dengan kecenderungan politik di parlemen lebih terfragmentasi dalam bebera- pa partai politik ${ }^{6}$. Tak heran bila kelahirannya tetap diwarnai tarik ulur kepentingan yang kuat. Akibatnya muncul beberapa pasal yang mengandung potensi permasalahan dan konflik. Bahkan, dalam perjalanannya persoalan dalam internal pemerintah sendiri, baik pusat maupun daerah sering terjadi.

Permasalahan yang cukup mencuat adalah hubungan pusatdaerah. Masalah ini berkaitan dengan seberapa besar dan pada pemerintahan mana wewenang dia dialihkan dari pemerintah pusat ke daerah?

Pada tahun 2004 dikeluarkan UU PD menggantikan UU No. 22 Tahun 1999. UU PD hanya memiliki kewenangan dan tanggung jawab terhadap pertahanan dan keamanan nasional, urusan agama, dan fungsi khusus seperti perencanaan ekonomi makro, sistem transfer fiskal, administrasi

pemerintah,

\footnotetext{
${ }^{6}$ Ignatius, Otonomi Daerah terjepit Tarikan Pusat Dan Masyarakat, Litbang Kompas
}

pengembangan SDM, pengembangan teknologi, dan standar nasional.

Kewenangan pusat berdasarkan UU No. 22 Tahun 1999 terdapat dalam pasal 7 ayat 1 dan 2 , yaitu :

1. Politik luar negeri;

2. Pertahanan keamanan;

3. Peradilan;

4. Moneter dan fiskal;

5. Agama;

6. Perencanaan nasional secara makro;

7. Dana perimbangan keuangan;

8. Pembinaan dan pemberdayaan sumber daya manusia;

9. Pendayagunaan sumber daya alam dan teknologi secara strategis.

Sementara kewenangan pusat berdasarkan UUPD terdapat dalam pasal 10 ayat 3 , yaitu :

1. Politik luar negeri;

2. Pertahanan;

3. Keamanan;

4. Yustisia;

5. Moneter dan fiskal nasional;

6. Agama.

Kewenangan propinsi berdasarkan UU No. 22 tahun 1999 :

1. Bidang yang bersifat lintas

kabupaten/kota, termasuk pekerjaan umum, perhubungan, kehutanan, dan perkebunan

2. Bidang tertentu : Perencanaan dan pengendalian pembangunan regional secara makro; pelatihan bidang tertentu, alokasi sumber daya manusia potensial dan penelitian yang mencakup wilayah propinsi; mengelola pelabuhan regional; pengendalian lingkungan hidup; promosi dagang dan budaya/pariwisata, 
penanganan penyakit menular dan hama tanaman, perencanaan tata ruang propinsi, kewenangan yang belum dilaksanakan kabupaten dan kota.

Kewenangan Propinsi

berdasarkan UUPD :

1. Perencanaan dan pengendalian pembangunan;

2. Perencanaan, pemanfaatan, dan pengawasan tata ruang;

3. Penyelenggaraan ketertiban dan ketentraman masyarakat;

4. Penyediaan sarana prasarana umum;

5. Penanganan bidang kesehatan;

6. Penyelenggaraan pendidikan dan SDM potensial;

7. Penanggulangan masalah sosial lintas kabupaten/kota;

8. Pelayanan bidang ketenagakerjaan lintas kabupaten/kota;

9. Pengembangan koperasi, dan UKM termasuk lintas kabupaten/kota;

10.Pengendalian lingkungan hidup;

11.Pelayanan pertahanan termasuk lintas kabupaten/kota;

12.Pelayanan kependudukan, dan catatan sipil;

13.Pelayanan administrasi pemerintahan

14.Pelayananadministrasi investasi termasuk lintas kabupaten/kota;

15. Penyelenggaraan pelayanan yang belum dilaksanakan kabupaten/kota;

16.Urusan lain yang diamanatkan UU.

Urusan pemerintahan secara nyata dan berpotensi meningkatkan kesejahteraan masyarakat sesuai dengan kondisi, kekhasan, dan potensi unggulan daerah yang bersangkutan. Dari pembahasan diatas dapat disimpulkan perbedaan konsep otonomi daerah yang diterapkan berdasarkan peraturan perundangundangan yang diberlakukan. Jika dibandingkan konsep otonomi daerah yang pernah ada dapat terlihat sebagai berikut :

- UUPD cenderung Desentralisasi

- UU No. 22 cenderung Desentralisasi

- UU No. 5 Tahun1974 cenderung Dekonsentrasi

- UU No. 1 Tahun 1945 cenderung Dekonsentrasi Pengertian Desentralisasi :

- Penyerahan urusan pemerintahan dari pemerintah atau daerah tingkat atasnya kepada daerah

- Penyerahan wewenang pemerintahan oleh pemda

- Penyerahan wewenang pemerintahan oleh pemerintah kepada daerah untuk mengatur dan mengurus urusan pemerintahan dalam kerangka NKRI ${ }^{7}$.

Pengertian Dekonsentrasi :

- Dekonsentrasi adalah pelimpahan wewenang pemerintahan oleh pemerintah kepada Gubernur sebagai wakil pemerintah kepada instansi vertikal di wilayah tertentu $^{8}$.

- Pelimpahan wewenang dari pemerintah kepada pejabat daerah. Pelimpahan wewenang dari pemerintah pusat kepada Gubernur sebagai wakil pemerintah dan/atau perangkat pusat didaerah

\footnotetext{
'Pasal 1 angka 7 UUPD

8 Pasal 1 angka 8 UUPD
} 
Tugas pembantuan adalah tugas untuk turut dalam melakukan urusan pemerintahan yang ditugaskan kepada pemda oleh pemerintah atau pemda oleh pemerintah atau pemda tingkat atasnya dengan kewajiban mempertanggungjawabkan kepada yang menugaskan.

Keberadaan

UUPD, seharusnya diikuti dengan PP sebanyak 26 dan PP tersebut harus dikeluarkan paling lambat 2 tahun setelah UUPD

Tetapi sampai batas 2 tahun, PP yang ditunggu baru 6 , sedangkan $20 \mathrm{PP}$ belum rampung dibahas. PP yang paling ditunggu adalah tentang pembagian urusan pemerintahan, antara pemerintahan pusat dengan pemda. PP ini sebagai pengganti PP No. 25 Tahun 2000. Tanpa adanya PP pembagian urusan pemerintahan, menyebabkan tumpang tindih kewenangan pusat. Propinsi dan kabupaten/kota.

\section{Reformasi Hukum}

Negara modern ${ }^{9}$ memerlukan sistem administrasi negara modern sebagai syarat bagi eksis nya

pemerintahan modern dan berfungsinya birokrasi pemerintahan yang modern, yang dimanifestasikan dengan indikator modernitas. ${ }^{10}$

9 S.F.Marbun, Dimensi Pemikiran Hukum Administrasi Negara, Ull, Press, Yogyakarta 2004 hal 48, menurutnya administrasi negara diwajibkan berperan aktif diseluruh segi kehidupan bermasyarakat sebagai salah satu ciri khas dari negara hukum modern

10 Mustopadidjaja AR, Format birokrasi NKRI bagi percepatan pemulihan
Indikator modernitas mengalami perkembangan dan perubahan, namun ada yang bersifat universal berlaku sepanjang zaman.

Dalam hukum administrasi negara, kebijakan otonomi daerah seharusnya berkaitan dengan bagaimana pejabat negara menjalankan fungsinya berdasarkan peraturan dengan memperhatikan

asas umum penyelenggaraan pemerintahan yang baik. Kebijakan dan keputusan yang diambil pemerintah harus dipertanggungjawabkan. Otonomi daerah yang diamanatkan undangundang menurut pemda untuk merealisasikannya dalam kebijakan daerah, salah satu bentuknya adalah dengan membuat dan melaksanakan perda yang mengatur wewenang dan tugasnya.

Philipus mengatakan hukum administrasi negara otonom adalah hukum operasional yang diciptakan pemerintah dan administrasi negara sendiri $^{11}$. Beberapa esensi dalam penyelenggaraan pemerintah yang perlu disadari adalah :

1. Kewajiban pihak administrasi negara dalam menjalankan fungsi dan wewenangnya berdasarkan prinsip pemerintahan yang baik dan bersih

2. Pengakuan terhadap HAM warga negara atas pemerintahan dan perilaku adminstratif yang baik;

dan pembangunan nasional. Disampaikan Pada Diskusi Dan Launcing IBSW Jakarta; 17 April, 2002

11 Phillipus M Hadjon, Pengantar Hukum Administrasi Negara, Gajah Mada University Press, 1993, hal.26 
3. Keaneka ragaman lingkup pelaksanaan pelayanan publik di Indonesia sebagai akibat dari adanya keragaman urusan dan kepentingan masyarakat yang harus dipenuhi melalui pelayanan publik;

Berkaitan dengan hal diatas, terdapat 3 hal yang perlu mendapat perhatian :

1. Rendahnya kualitas pelayanan publikyangdilaksanakan

aparatur pemerintah dalam menjalankan tugas dan fungsinya.

Dalam kerangka hukum administrasi positif Indonesia saat ini telah diatur standar minimum kepatuhan terhadap standar minimum pelayanan publik tersebut masih belum terlihat manifestasinya dalam pelaksanaan tugas aparatur pemerintahan.

2. Birokrasi panjang (red-tape bureau cracy) dan tumpang tindih kewenangan pemerintah pusat maupun pemda, yang menyebabkan penyelenggaraan pelayanan publik menjadi panjang dan melalui proses yang berbelitbelit, sehingga tidak mustahil

memperbesar kemungkinan timbulnya ekses dalam wujud ekonomi biaya tinggi, terjadinya penyalah gunaan wewenang $\mathrm{KKN}$, dan perlakuan diskriminatif.

3. Rendahnyapengawasan masyarakat(socialcontrol) terhadap penyelenggaraan pelayanan publik sebagai akibat dari ketidak jelasan standar dan prosedur pelayanan serta prosedur penyampaian keluhan pengguna jasa pelayanan publik. Tidak cukup dirasakan adanya tekanan sosial (social Pressure) yang memaksa penyelenggara pelayanan publik harus memperbaiki kinerja.

Pelayanan publik berorientasi kebutuhan dan kesejahteraan masyarakat harus memberikan pedoman yang mengikat aparat dan masyarakat tentang :

1. Jaminan pelayanan dikelola professional dan bertanggung jawab oleh pejabat pemerintahan yang berwenang untuk memberikan pelayanan publik (Code of Conduct for Public Servant)

2. Transparansi dan akuntabilitas pelayanan publik diselenggarakan petugas yang berwenang

3. Jaminan pelayanan publik dibutuhkan masyarakat dapat diperoleh secara layak, wajar, dan proporsional

4. Jaminan secara yuridis memperoleh pelayanan optimal didukung oleh standar mekanisme pengajuankeluhanyang memadai.

Sudah seharusnya reformasi sistem pemerintahan penyelenggaraan pemda dibarengi dengan reformasi hukum administrasi negara sebagai tuntutan kepastian hukum.

Reformasi hukum administrasi negara $^{12}$ dapat dilakukan melalui:

12 Roy V Salomo, Reformasi Administrasi Pemda, makalah disampaikan pada Desiminasi Strategi Reformasi Penyelenggaraan Pemda Sebagai Bagian dari Pembangunan dan Pembangunan Administrasi Negara Berdasarkan UUD 45. Medan 29 Oktober 2008 
1) Paradigma, yaitu melingkupi :

- Welfare State peran pemerintah

- Good Governance

- New Public Management

2) Tujuan reformasi administrasi :

- Meningkatkan peran 3E (efesiensi efektifitas, ekonomi) pada pemda

- Mengembangkan kepemimpinan berdasarkan Good Goverment

- Menciptakan manajemen publik yang professional pada pemda

Dalam menjawab tuntutan reformasi hukum administrasi negara hal pertama yang harus dilakukan adalah menciptakan undang-undang yang secara khusus dan mandiri, mengatur hukum administrasi negara ${ }^{13}$. Hingga saat ini pengaturan yang menyangkut kebijakan dan kewenangan aparatur pemerintah belum terkodifikasi dan sistematis

$$
\text { Pada saat ini RUU }
$$

Administrasi pemerintah telah dibahas ditingkat kementerian dan disosialisasikan kepada masyarakat. Bahan dan materi dari pasal yang akan ditetapkan telah dirancang.

Namun ampres belum diturunkan sehingga RUU ini belum dapat dibahas di DPR. RUU Administrasi Pemerintahan merupakan inisiatif pemerintah dan telah disusun sejak 2004. RUU tersebut merupakan instrument hukum untuk reformasi

\footnotetext{
${ }^{13}$ Wasito Putro, Penyusunan KUH Administrasi Negara, makalah disampaikan dalam Desiminasi Strategi Reformasi Penyelengaraan Pemda Sebagai Bagian dari Pembangunan dan Pengembangan Administrasi Negara Berdasarkan UUD 45. Medan, 29 Oktober 2008
}

birokrasi serta menutup peluang terjadinya $\mathrm{KKN}^{14}$.

RUU ini mengatur antara lain tentang kewenangan administrasi pemerintahan. Pejabat diharuskan netral dalam membuat keputusan pemerintah yang akibatnya memberatkan, pejabat wajib mendengar pendapat pihak yang berkepentingan, "ini persyaratan reformasi birokrasi, dengan demikian Masyarakat mendapatkan kepastian hukum," katanya 15

Dalam reformasi hukum administrasi negara yang pada tujuannya adalah memberikan dasar penguatan bagi penyelenggaraan pemerintahan dalam mengambil kebijakan terhadap daerah, hingga masyarakat dapat terjawab dengan baik. Partisipasi dan peran seluruh komponen yang ada yakni pemda, masyarakat dan dunia usaha menjadi ujung tombak dalam kebijakan daerah.

Sejalan dengan itu, menurut Wa De dan Philipps diberikan penegasan peran hukum negara dengan batasan sebagai berikut :

1. Kaidah hukum yang mengatur bagaimana organ kekuasaan negara menjalankan kekuasaannya

2. Kaidah hukum yang mengatur kekuasaan antara lembaga negara, dan antar lembaga negara dengan masyarakat.

3. Kaidah hukum yang memberikan jaminan dan perlindungan bagi

\footnotetext{
${ }^{14}$ Berita Sore, 27 Juni 2008

${ }^{15}$ Menteri Negara Pendayagunaan Aparatur Negara
} 
masyarakat maupun administrasi negaral $^{16}$.

Secara garis besar, partisipasi masyarakat terhadap kebijakan daerah dapat dilihat sebagai berikut:

a. Setiap pembuatan kebijakan, baik berupa keputusan kepala daerah maupun perda, wajib melibatkan masyarakat untuk berpartisipasi;

b. Setiap kebijakan yang tidak melibatkan masyarakat menyebabkan kebijakan daerah dibatalkan pemerintah atasan;

c. Masyarakat berhak mengkritisi dan mengevaluasi kebijakan daerah yang telah ada, dan apabila dipandang perlu dapat mengajukan usul agar kebijakan daerah yang dinilai masyarakat tidak sesuai dengan kepentingan masyarakat dan tuntutan keadaan, ditinjau kembali dan apabila perlu diusulkan dicabut;

d. DPRD mempunyai tugas menampung dan menindak lanjuti aspirasi;

e. Masyarakat mempunyai hak mencari dan memberikan informasi tentang penyelenggaraan negara, serta menyampaikan saran dan pendapat terhadap kebijakan penyelenggaraan pemda ${ }^{1 / 2}$.

Perkembangan Iebih lanjut juga menunjukan semakin lekat nya nilai-nilai kemanusiaan seperti keadilan, demokrasi, partisipasi dan HAM dalam penyelenggaraan negara dan pembangunan sebagai indikator

\footnotetext{
${ }^{16}$ Wade dan Philips, Constitusional Law, Long man Green \& Co, London 1957 17 Otonomi Daerah Dan Permasalahannya, Makalah, 10 Agustus 2002 di Yogyakarta
}

kemajuan dan tingkatan modernitas sistem dan proses administrasi negara dan pembangunan suatu bangsa. Perkembangan yang menggema adalah penyelenggaraan pemerintahan yang baik (Good Govermance) yang komit terhadap nilai dan prinsip "kepastian hukum, partisipasi, transparansi, sensitivitas, profesionalitas, efisiensi, efektivitas, desentralisasi dan Jaya saing",18.

\section{Penutup}

Dari pembahasan yang dilakukan dapat ditemukan kesimpulan :

1. Hukum administrasi negara merupakan instrument penting dalam penyelenggaraan kekuasaan yang dilakukan pemerintah (baik bagi pemerintah pusat maupun pemda)

2. Adanya kewajiban pihak administrasi negara untuk menjalankan fungsi dan wewenang nya berdasarkan prinsip pemerintahan yang baik dan bersih.

3. Reformasi hukum administrasi harus segera dilaksanakan dengan menetapkanRUUHukum

Administrasi Pemerintahan menjadi Undang-Undang

4. Kepemerintahan yang baik adalah kepemerintahan yang dapat melakukan proses koordinasi, pengendalian dan penyeimbangan antara pemerintah dengan rakyat di dalam pemerintahan. Pemerintah dapat menjunjung tinggi nilai keinginan atau kehendak rakyat,

${ }^{18}$ Mustopadidjaja AR, Op. cit 


$$
\begin{aligned}
& \text { yang dapat meningkatkan } \\
& \text { kemampuan rakyat mencapai } \\
& \text { kemandirian melaksanakan } \\
& \text { pembangunan berkelanjutan dan } \\
& \text { menjunjung tinggi keadilan di } \\
& \text { dalam masyarakat }
\end{aligned}
$$

\section{DAFTAR PUSTAKA}

Forum Penelitian Daerah, Otonomi Daerah dan Permasalahannya, Seminar Nasional, 10 Agustus 2002, Yogyakarta

Ignatius, Otonomi Daerah Terjepit Tarikan Pusat Dan Masyarakat, Litbang Kompas.

Lembaga Administrasi Negara, Jakarta 2005

Miriam Budiarjo, Dasar-Dasar limu Politik, Gramedia, Jakarta, 1982

Philipus m Hadjon, Pengantar Hukum Administrasi negara Gajah Mada University Press, 1993

Roy Valiant Salomo, reformasi Administrasi Pemerintahan daerah, Medan, 29 Oktober 2008

S.F. Marbun, dimensi-Dimensi Pemikiran Hukum Administrasi Negara, UII, Press, Yogyakarta, 2004

Wade dan Philips, Constitusional Law, Longman Green \& Co, London, 1957

Wasito Putro, penyusunan Kitab Undang-Undang Hukum Administrasi Negara, Medan, 29 Oktober 2008

Berita Sore, 27 Juni 2008 http://www.rakbuku.com/tsoftcopy/t hk.040.doc 